\title{
The dynamics of oil and social movements in the Niger Delta of Nigeria
}

\author{
Victor Ojakorotu, University of KwaZulu-Natal, South Africa
}

Nigeria, a major black state in the world today, is currently grappling with youth militancy and unmitigated violence on a large scale, particularly in the Niger Delta where oil exploration and exploitation have occurred for years without proper care and protection of the environment. As a consequence, local people have reacted in volatile ways to oil activities in the region, and the Niger Delta has become more conflict-prone than any other region in Nigeria. The region has been the epicentre of numerous overlapping conflicts: between oil bearing/host communities and oil companies (mainly over land rights or compensation for ecological damage); between oil producing communities and the government (over increased access to oil wealth); and between and among ethnic groups (over claims to land ownership and sharing of amenities).

The long-standing Niger Delta crisis has had serious consequences, including the loss of lives, wanton destruction of property, and disruption of oil activities. The Nigerian state is seemingly overwhelmed by the complexity of this quagmire in spite of successive governments' efforts to address the structural dynamics that underpin the region's problems. In addition a democratic opening (since 1999) seems to have provided an outlet for increased militancy by the youth of the region, thus posing an enormous challenge to national stability, which historically has been sustained by state force. Indeed, the state at different times has employed force to suppress the agitation or aspiration of local peoples. For instance, the attempt by the Niger Delta Volunteer Force, led by Isaac Adaka Boro, to secede from Nigeria in 1966, was crushed by federal government forces. 
This paper highlights the plight of the people of the Niger Delta, the interests of the principal actors, and the sudden upsurge in the number of social movements in the 1990s to challenge the state and oil companies' activities in the region.

\section{Causes of conflicts in the Niger Delta}

It is not difficult to fathom the overt causes of the conflicts in the Niger Delta region. Broadly speaking, it can be claimed that federalism as practised in Nigeria has failed to take into account the fears, needs and aspirations of the minorities that make up the Niger Delta region. The skewed structure of the Nigerian state has precipitated fiscal centralisation that favours the Federal Government and the country's ethnic majority. The overbearing domination by the Federal Government has made it difficult for the oil-bearing communities to gain, as they would define it, equitable access to the wealth derived from their own resources. As a result, the people of the Niger Delta have led a wave of agitation for greater control of those resources. Such agitation has, more often than not, assumed violent dimensions. Therefore, it can be said that resource disparity in access, control, and wealth distribution, has been the basis of the conflicts between the oil companies, the Nigerian government, and the communities in the Niger Delta, for decades.

At the heart of the persistent crisis in the region is the deprivation and marginalisation of the local people by the state as a consequence of the distribution of the wealth emanating from the oil produced from local lands and waters. The agitation has reacted against the dearth of critical infrastructures that support life. The people of the region complain of lack of good health care, poor infrastructure, unemployment, and endangered livelihoods. In addition, they have argued that the wealth from their lands and waters is being used to develop big cities and areas in other parts of the country where oil is not produced. From my on-the-ground assessment of the region, the Delta peoples and their environment have been neglected for so long that many local people claim they have nothing to live for; moreover, in doing what they can do to make ends meet, more often than not, their activities are against the law, a case in point being the vandalisation of oil pipelines. The exclusion and deprivation of whole communities from access both to oil wealth and to the physical development of the area has naturally contributed to the region's tensions, violence and conflict. 
It goes without saying that oil exploration and exploitation have far-reaching consequences for the environment. Oil-related activities have done much damage to the fragile Niger Delta region, and to the health of its people as well. Notable impacts of oil extraction have been the loss of biodiversity, ecological devastation/degradation, and the destruction of mangrove forests. The popular perception in the region has been that the operations of the oil companies have led to the gradual destruction of the region's fragile ecosystem. And whenever the oil companies fail to take responsibility for the damage done to the environment, the state's incapacity to address the demands of the local people has been responsible for the conflict between the people of the community (particularly the youth) and the oil companies. In addition, the seeming failure of governments at all levels to tackle the problem has engendered conflicts between the local people and the oil companies, on the one hand, and between the local people and the government on the other.

As a result, ethnic identities and relations have become weapons for contestation in the Niger Delta. Ethnic identities have assumed the character of a mobilizing factor for contesting access not only to oil wealth but also to political power. Ethnicity has also been staked in the organisation of social forces in the struggle against perceived injustices (Obi 2002a). Ethnic identities have further divided the people of the Niger Delta, often resulting in fratricidal warfare. In the recent past, ethnic groups have acted politically in defence of their interests vis-à-vis those of competing groups. In most cases, inter-ethnic rivalry has arisen over land ownership. The series of clashes between the Ijaws and Itsekiris of the Niger Delta are a case in point.

From the author's interviews with the people from Afiesere and Uzere communities in the Niger Delta, it is clear that the people of the Niger Delta have been disempowered and disinherited from their land through the instrumentality of legislation such as the Petroleum Act (1969), the Land Use Act (1978), and the Lands Act (Title Vesting) (1993). These laws vest ownership and control of lands, navigable waters, and the resources found therein, in the hands of the Federal or State Government.

Environmental activists in the region argue that such legislation stifles local initiatives at protecting the environment. Community agitation aimed at the abolition of the 
legislation, and the reluctance of the government to accede to such requests, have all intensified the activism for resource control, protests, brigandage, and violence.

Given the assistance of oil multinationals to the Nigerian police and the Nigerian Navy in the region, and the total dependence of the state on oil since the 1970s, it is arguable that there exists an 'unholy alliance' between the Federal Government and the oil companies. People from the oil-bearing communities contend that the Government almost always identifies with, and defers to, the interests of the oil companies. The Governor of Nigeria’s Akwa Ibom State, Obong Victor Attah, posits that in doing so, the Federal Government gives the oil multinationals the impression that local communities and states in the Niger Delta do not matter, and that all that is needed is continued collaboration and understanding between the central government and the transnational oil companies. Clearly, the government's participatory interest in the oil companies is an impediment to fulfilling its obligations to the people of the Niger Delta.

As a result, the Niger Delta has seen both the militarisation of and the proliferation of arms throughout the oil-producing region. Successive governments have sought to contain the violence through troops and weapons deployment. The aggrieved communities have, in turn, taken up arms against the security forces to counter what they have long regarded as an uncalled-for siege on their communities. The militarisation of the region by the government finds expression in the several cases of military invasion of oil-producing areas experiencing social unrest. Often, massive troop mobilizations by the state have followed cases of agitation by the people against environmental disasters and perceived neglect.

\section{Oil multinationals in the Niger Delta}

It must be pointed out that the Nigerian oil industry has been strongly dominated by foreign oil companies and their expatriate workers for decades. Lack of required technology and massive capital involvement in oil exploration have given the foreign oil multinationals an edge over local corporations, a development that has been interpreted by some commentators as a strategic means of denying the people and Niger Delta states the dividends of the resource that belongs to them. The scenario in the oil 
industry is that of an alliance between the state and foreign oil companies that does not need to take into consideration the interests and aspirations of local peoples.

Historically, the involvement of oil multinationals in the Nigerian economy predates independence with the granting of the mineral oil concession to the Shell-d'Arcy Petroleum Development Company by the British colonial government in 1938. The discovery of oil in commercial quantities by this company stimulated the interests of other oil companies in the late 1950s, namely: Mobil Exploration Nigeria Ltd, an affiliate of the American Socony-Mobil Oil Company; Tennessee Nigeria Inc. (1960), an affiliate of the American Tennessee Gas Transmission; Nigerian Gulf oil Co (1962), an affiliate of American Gulf Oil Company; and Nigerian AGIP Oil Co (1962), an affiliate of the Italian government-owned ENI (Schatzl 1969).

The incapacitated nature of the Nigerian state after independence (attained October 1, 1960), gave room for a series of joint ventures between these oil companies and the state through the Nigerian National Petroleum Corporation (NNPC). The companies that are in joint venture agreements with the NNPC are the Shell Petroleum Development Company (SPDC), Chevron Nigeria Limited (CNL), Mobil Producing Nigeria Unlimited (MPNU), the Nigerian Agip Oil Company Limited (NAOC), Elf Petroleum Nigeria Limited (EPNL), and the Texaco Overseas Petroleum Company of Nigeria Unlimited (TOPCON). Apart from these oil companies, which operate a joint venture with the NNPC, others also operate in Nigeria. These companies include Pan Ocean, British Gas, Tenneco, Deminex, Sun Oil, Total, Statoil, and numerous other local firms (Ojakorotu 2003, fieldwork findings).

The precarious situation in the Niger Delta occurred once oil became the economic mainstay of the Nigerian state. The ascendancy of oil changed the political equation of the entire country in favour of the major ethnic groups that reneged on the initial derivation principle, which had given advantages to the regions at a time when cocoa, groundnut and other agricultural produce were the main sources of foreign exchange in the country. The cumulative effect of this new development has been the recurrence of violence among the ethnic groups of the Niger Delta as they have emerged to challenge the 'political schism' between the dominant and minority ethnic groups in Nigeria. 
Relations between the minority and the major ethnic groups now reflect the 'weagainst-them' logic.

The plight of the minority ethnic groups in Nigeria is structurally linked to the creation of the Nigerian state in 1960. However, making that link supports and validates the naïve premise that the colonial enterprise precipitated all subsequent troubles in colonised spaces, while denying historical antecedents and predating tensions. Oral histories suggest otherwise, pointing to an enduring legacy of ethnic conflict and tribal conflict around territory and modes of production. Internecine slave castes/tribal servitudes and land wars testify to this. One aspect of the colonial encounter was often the co-production of an overarching alliance between colonised ethnicities to evict the coloniser, thus making the unitary state congruent to colonial boundaries. It must be stated that the initial resistance by many of Nigeria's ethnic groups was uncoordinated and without proper focus. However, a change to the modus operandi of the struggle became evident in the early 1990s with the Movement for the Survival of Ogoni People (MOSOP), which emerged to challenge the state apparatus and foreign oil companies, and to assert the need to address the demands of the local people in the oil region.

Given the defective nature of Nigerian federalism, with the centralization of power and domination of minorities by the three dominant ethnic groups - the Hausa/Fulani, Yoruba and Igbo — and given the double standards of foreign oil multinationals, as well as other internal contradictions within the Nigerian state, the people of the Niger Delta were left with no option but peaceful protest, and later, violence, in their struggle against the state and foreign oil companies that operate in the region.

\section{The emergence of social movements in the Niger Delta}

The globalisation of capital has played an important role in the confrontation between oil multinationals and the social movements that emerged in the region, especially the Ogoni Movement and the Ijaw Youth Council. Multinational Corporations represent, and are positioned at the centre of, a 'global structure of material accumulation which simultaneously concentrates wealth and energy in certain locales' (Saurin 1996, 42). The rise of ethnic militias in the Niger Delta region in the early 1990s (as was discovered by the author in fieldwork) was informed by the marginalisation and social deprivation of the minorities. However, various internal policies propounded by the 
state and oil companies that gave rise to underdevelopment, combined with external factors like the globalisation of the international system, also strongly influenced the formation of these social movements. The interplay between the internal and external factors thus established a strong linkage between local non-government organizations (NGOs) and social movements, and international non-government organizations (INGOs), and created the setting for the internationalisation of the Niger delta crisis.

With this scenario, local resistance seems to have taken shape and become locally grounded, a reflection of the fact that the very existence of the Ogoni and other minorities in oil-bearing communities had come under serious threat. The environment was destroyed, there was no basic infrastructure, and the Ogonis and other minority groups also faced repression from both the multinational oil companies and the federal government. More importantly, the Nigerian legislation dealing with oil and mineral resources removed control of the land from the people: the land, and its oil reserves, had been ‘co-opted into the globalised capitalist economy’ (Giddens 1990, 18).

The transformation of the Niger Delta struggle into a mass social movement found expression in the presentation of the Ogoni Bill of Rights to the Nigerian state in 1990 by MOSOP. Attempts by the Ogoni people to stem further degradation of their environment and other negative consequences of oil production, along with the neglect of the region by the state, provided the impetus for the Bill. The Nigerian Civil War (1967-1970), and the creation of a federalised state to address the demand of the minorities, failed to secure for the oil minorities the control of oil resources. At the same time, the structural adjustment that widened social and power cleavages within the region, and changes in global politics in the post-Cold War era, which emphasized the right to self-determination and autonomy by minority ethnic groups (Obi 1999), gave impetus to the struggle in the region.

Given these factors, MOSOP, under the leadership of Ken Saro-Wiwa, assumed a more dynamic and purposeful character as it adopted far-reaching tactics in the cause of the Ogoni. The organization sensitised the Ogoni people to their predicaments and enabled their mobilization against the state and Shell Petroleum Development Company (SPDC) through demonstrations, the blockade of oil installations, conferences, press releases, and articles in local and international media. 
In order to strengthen their chances for self-determination, the Ogoni focused on gaining the sympathy and necessary attention from the international community about the need to address the exploitation, repression and ecological devastation the community was confronting. The organization appealed for support through lecture tours, documentaries, and eyewitness accounts. It also used the platform of international human rights organizations to put pressure on Shell and the Nigerian state to recognize and respect the rights of the Ogoni (Omoweh 1994). However, the Ogoni failed to consider that the military, which dominated the Nigeria political terrain in the 1990s, appeared to have little regard for the concepts of human rights and moral principles upon which they (the Ogoni) based their campaign (Carr, Douglas and Onyeagucha 2001). The adoption of non-violent methods by the Ogoni in the face of military opposition severely curtailed the organization's capacity to influence the relationship between the local people and their 'foes' - the multinationals and the Nigerian state.

It is interesting to note that the Ogoni adopted these methods or strategies because earlier methods used by the local elites before MOSOP's inception had failed.

Explanations for that failure lie in the elite control of national political parties, and the organized electoral fraud that made a nonsense of the voting system. For example, the elite in the Ogoni Central Union (OCU) and Kagote ${ }^{1}$ refused to involve the masses in the struggle for self-determination. In MOSOP, by contrast, the youth in the region had been given more political roles to play; indeed, a key strategy adopted by the group was to provide every member of the community an opportunity to help in reversing the imbalances of the Nigerian federation.

Despite the huge success of this movement in bringing an otherwise local issue to the platform of international discourse, the struggle of the local people in the 1990s witnessed a severe set back with the death of Ken Saro-Wiwa, which greatly reduced international support for local resistance. Ken had personified the struggle. More importantly, the political divisions that erupted after the Saro-Wiwa's death confused the international community in directing its support for the struggle of MOSOP and

\footnotetext{
${ }^{1}$ The precursor of MOSOP, Kagote was an Ogoni elite-leader organization that was active in Delta politics following federal government murders of Ogoni leaders in 1994 and 1995.
} 
other ethnic groups in the region. Moreover, since the Nigerian state was not democratic until mid-1999, the INGOs were forced to hold consultations with the military. Unfortunately, the military leaders were not accountable to the people, nor was there any forum in which local peoples could discuss the pressing issues of the Niger Delta.

It is pertinent to state that MOSOP was able to achieve considerable success due to the commitment of its leaders to the struggle. Prior to the formation of MOSOP in the early 1990s, local leaders were not totally committed to the struggle, as was later the case under MOSOP. Ken Saro-Wiwa's early experiences with the Igbo ethnic group in his days in Nsukka awakened his ethnic consciousness in the 1960s. He had given his full support to the federal side during the Nigerian Civil War as a way of overcoming the Ibo domination of the Niger Delta minorities. Increasingly, however, he realised that the liberation of Ogoniland could not be achieved through the Nigerian mechanism of state creation that followed the Civil War. Therefore, Saro-Wiwa, an intellectual, environmentalist and writer, gradually came to support the self-determination of all ethnic nationalities, including the Ogoni. Apart from his wholesale support for MOSOP, he established the Ethnic Minority Rights Organisation of Africa (EMIROAF). He was an apostle of non-violence; his weapons were his pen, brain, faith, and commitment to the liberation of the Ogonis, and, by extension, of other minorities. Ken Saro-Wiwa was able to use his popularity to garner both national and international support for the cause of the Ogoni, but he was eventually defeated: on November 10, 1995, he was executed by the General Sani Abacha dictatorship. There is an intriguing historical irony among the prominent actors in the Niger Delta, Isaac Boro, Ken Saro-Wiwa and Dokubo Asari, who have struggled for self-determination, as the editorial in the Nigerian Guardian noted: 'the first and third led armed struggles against the Nigerian state [and] they escaped with their lives and were later reconciled with the state. The second, an intellectual, preached and practised non-violent protest but he lost his life in the hands of the state' (2004). As a consequence, the minorities began to realize that the non-violent method was not a viable option in the struggle for justice and self-determination in Nigeria.

Against the above background, it is necessary to understand the relationship between the state and the Ogoni communities. Some of the major protests in Ogoniland, and the 
responses of the state and the foremost oil company (Shell) between 1990 and 2003, are quite telling. As can be inferred from the state response to Ogoni protests, state violence can be broadly categorised into three types: harassment of Ogoni leaders through arrests, detention and surveillance; masterminding of violent conflicts between Ogoni and their neighbours (used as a pretext to repress the Ogonis), and direct violence, the use of the armed forces and police and extra-judicial killings, as occurred with Saro-Wiwa and the 'Ogoni 9' (nine Ogoni leaders killed by the Nigerian government in 1995) (Ibeanu 2000).

As noted above, the death of Ken Saro-Wiwa changed the course of events in the Niger Delta. It has been rightly argued that his death has given the ethnic minorities of the region the leverage to speak in a 'new voice and demand ... that their wishes and aspirations be factored into the Nigerian projects' (Okonta and Oronto 2001). This development has also encouraged the local people to insist on self-determination, for a structure within the Nigerian federal framework that will promote true federalism, equity, justice and negotiated cooperation. That said, Shell has also been called to account and compelled to pay reparation for environmental devastation in the Niger Delta. Resistance by the Ogoni against oil production has historically been considered a direct threat by the Nigerian state and Shell, which is answerable to its headquarters in Britain. Against this background, the centrality of oil to the survival of Nigerian state, and the oil companies' drive for profit maximization, lay behind the militarisation of, and gross violation of human rights in, the region by the state and oil multinationals alike.

The internal contradictions and disputes that emerged within the MOSOP in the late 1990s eventually caused the mantle of leadership in the struggle for the Niger Delta to be passed to the Ijaws. However, it must be stated that, for the Ijaws, this struggle began in the 1960s. The Ijaws are the fourth largest ethnic group in Nigeria, after the three dominant ones, and are the largest ethnic group in the Delta region, with a population of about eight million, most of whom are dependent on fishing. The earliest attempt by any ethnic group to challenge injustice within the Nigerian federation was carried out by the Ijaws under Adaka Boro during his 'twelve day revolution' in February 1966. The ‘twelve day revolution' of the Niger Delta Volunteer Force (NDVF) was an attempt to end the marginalisation of the region's minorities within the 
Nigerian federation, and arose from suspicions that the military government of General Aguiyi Ironsi would take control of the region’s oil resources (Okpu 1977). Adaka Boro, an Ijaw man born in Kaiama, an ancient town in the present Bayelsa State of Nigeria, lived for only thirty years (1938-1968), but his cause was later championed by fellow ethnic groups in the 1990s, some three decades after his death. In remembrance of his vision and struggle for his people, the Ijaw Liberation Charter was named the Kaiama Declaration in December 1998.

The struggle of MOSOP, however, laid the foundation for a resurgence amongst the region's ethnic groups in challenging the state's and oil multinationals' policies. As Obi has argued, the resurgence of the Ijaw in under the leadership of the Ijaw Youth Council (IYC) 'built upon the lessons from the Ogoni experience ... [it] sought to put an end to the divisions among the Ijaws in the six states of the federation, as the fourth largest ethnic group in Nigeria, and the most preponderant oil minority group' (2002b, 6). Since the 1990s young Ijaw activists have regrouped into different groups in the multiple struggles against economic exploitation, corporate violence, environmental degradation, and political oppression in the Niger Delta. These groups include the Egbesu Boys of Bayelsa, the Chicoco Movement, the Ijaw Youth Council, the Federated Niger Delta Ijaw Communities, and the Niger Delta Volunteer Force.

The impact of oil exploration on the environment, and the policies of the state and oil companies in the Niger Delta, led the various groups of Ijaw youth in the Niger Delta to issue the Kaiama Declaration on December 11, 1998. The Declaration demanded the immediate withdrawal of all military forces from Ijaw land. In addition, the Declaration averred that any oil company that employed the services of the Nigerian security services to protect its facilities was viewed as an enemy of the Ijaw. The Ijaw Declaration also strongly expressed solidarity with other ethnic groups that shared its vision of self-determination and justice, such as MOSOP.

The internationalisation of the Niger Delta crisis has thus forced the key players in the crisis - the Nigerian state and the oil multinationals - to rethink their stance on the people's plight. However, their response has been two-fold and contradictory: hard and soft. On the soft side, the state has made some efforts to address the developmental needs of the people through agencies like the Niger Delta Development Commission 
(NDDC), while some of the oil companies (Shell in particular) have increased their support for community development programs and adopted an ethos of social responsibility. However, while this marks an improvement compared to the preinternationalisation period, these efforts are still insufficient when viewed against the backdrop of what is being done to the Niger Delta region in economic and environmental terms, and against the massive poverty that still persists in the region. On the other hand, both the state and the oil multinationals have overtly and covertly continued their hard response of militarising the region under the guise of security, thus inflicting more violence on the people. There is thus great need for a renewal of sustained efforts to further internationalise the Niger Delta crisis by exposing the exploitation and environmental despoliation not only of Ogoniland, but also of other communities that suffer the same, if not worse plight, than the Ogoni people.

\section{Closing reflections}

As this paper suggests, a redefinition of the parameters of coexistence within the Nigerian state has become imperative. This reflects calls made in 2005 to convene a National Conference of ethnic nationalities at which all stakeholders in the polity could come together and discuss the future of Nigeria. Such a conference, advocates claimed, could fashion a workable mechanism for restructuring the country in such a way that each region would have its own fair share of available opportunities and resources. The conference would thus address the fundamental question of Nigerian federalism by calling for a federal restructuring that would adequately take care of and acknowledge minority interests.

The National Political Reform Conference (NPRC) that was eventually convened in 2005 in Abuja, Nigeria was initially conceived as an opportunity to redress these concerns and the structural imbalances in the Nigerian state. However, the lack of consensus on issues that affect the Niger Delta not only stalled proceedings but also undermined efforts at building national solidarity. The people of the Niger Delta rejected the recommendations of the conference as far as the issues affecting the Niger Delta were concerned. The NPRC, in the opinion of the people of the Niger Delta, had failed to address the fundamental issues that threaten the continued existence of the Nigerian state. 
Despite these failures, it remains clear that achieving a true federalism in Nigeria must be an integral part of the project to create and nurture democracy and good governance, and to satisfy the legitimate aspirations of ethnic minorities as well. The Nigerian government should devise a workable environmental policy that would regulate oil operations in the Niger Delta. Setting up environmental agencies is not enough. Effective machinery should be put in place for the strict enforcement of environmental legislation. In addition, the operations of multinational oil companies should be made more accountable to the local people. The government should not compromise the welfare and survival of its citizens for the sake of its profit-motivated partnership with the oil companies.

Recent efforts at preparing an Integrated Regional Master Plan for the development of the Niger Delta are commendable. The people of the region have, however, been expressing strong reservations about the Plan since the Integrated Regional Master Plan Agreement was signed in October 2001. If it is to succeed, the initiative must be people-centred and must adopt the bottom-up approach. Both government and the oil communities in the Niger Delta should embrace dialogue. The present crisis in the region is partly being fuelled by the lingering militarist disposition of both sides. The frequent deployment of military forces to the Niger Delta to quell local riots in recent years has further militarized local ethnic militia. In order to stem the tide of violence and armed confrontation in the region the government should systematically deemphasize the use of force, and embrace the aggrieved communities in meaningful dialogue. There should be delegitimisation of force in favour of legitimisation of dialogue and consensus-building in order to promote a true federalism that would allow the minorities to benefit from the system.

\section{Reference list}

Carr, S., Douglas, C. \& Onyeagucha 2001, ‘The Ogoni people’s campaign over oil exploitation in the Niger Delta' in A. Thomas, S. Carr, and D. Humphrey (eds) Environmental Policies and the NGOs Influence, Routledge, London, pp. 150170.

'Editorial' 2004, The Guardian Lagos, 21 October.

Giddens, A. 1990, The Consequences of Modernity, Cambridge University Press, Cambridge.

Human Rights Watch 1999, 'The price of oil: corporate responsibility and human rights violations in Nigeria's oil producing communities', Human Rights Watch, New York. 
Kaemi, T. 1982, Isaac Boro: Twelve Day Revolution, Benin City, Nigeria.

Obi, C. I. 1999, 'Oil, environment and conflict in the Niger Delta', The Quarterly Journal of Administration 30. 1 (June 1999): 15-34.

Obi, C. I. 2002a, 'Environmental movements in Sub-Saharan Africa: a political ecology of power and conflict,' Paper presented at the United Nations Research Institute for Social Development/University of Witwatersrand Conference on Environmental Conflict, Participation and Governments, Johannesburg, August 30.

Obi, C. I. 2002b, 'New wine in new skin? Generation dimensions to the struggles for resource control in the Niger Delta and the prospects for the nation-state project in Nigeria,' Paper delivered to laureates of the CODESRIA 2002 Governance Institute, CODESRIA, Dakar, Senegal, August 12-16.

Okpu, U. 1977, Ethnic Minority Problems in Nigerian Politics: 1960-1965, Uppsala, Studies Historical Upsaliensa.

Omoweh, D. A. 1994,' The role of Shell Petroleum Development Company and the state in the underdevelopment of Niger Delta of Nigeria', PhD Thesis, Obafemi Awolowo University, Ile-Ife, Nigeria.

Saurin, J. 1996, 'International relations, social ecology and the globalization of environmental change’ in J. Vogler \& M. Limber (eds), The Environment and International Relations, Routledge, London, pp 46-66.

Schatzl, L. H. 1969, Petroleum in Nigeria, NISER, Nigeria. 